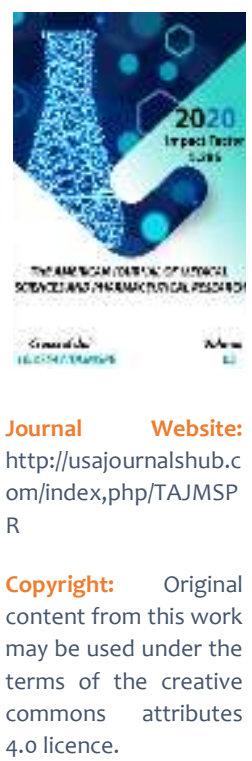

\title{
Safe Grow Of The Uterus
}

Otajonova Dilfuza Otabek Qizi

Student, Professional Education, Pediatric Faculty Of The Urgench Branch Of The Tashkent Medical Academy, Uzbkistan

\section{ABSTRACT}

Currently, there is a sharp increase in gynecological diseases in women. These are especially dangerous and safe tumors. In this article, we will focus on safe uterine tumors.

\section{KEYWORDS}

Uterus fibroids, ovarian cystoma, hormones, endometriosis, cyclic changes, gynecological diseases, clinic, treatment.

\section{INTRODUCTION}

Uterus fibroids are benign, hormone-prone tumors that are made up of muscle tissue, fibromyoma, and connective tissue. Fibroids are a common disease that occur in $10-27 \%$ of gynecological patients, $20 \%$ of patients over 30 years of age, and $40 \%$ of patients over 40 years of age. In women, uterine fibroids can be caused mainly by hormonal changes, such as damage to the hypothalamus, pituitary-adrenal glands, any part of the relationship between the ovaries, and changes in the uterus, especially hyperplasia of the myometrium.

Examination of the pituitary gonadotropin hormone revealed a low level of the hormone progesterone in the body during the menstrual 
cycle, which in turn leads to a deficiency of the second period of the menstrual cycle. In 70$80 \%$ of cases, uterine fibroids indicate the presence of a pathological menstrual cycle in patients. Based on clinical and experimental studies, it is assumed that hormonal changes that occur in the female body, in particular the overproduction of the hormone estrogen, play an important role in the formation of uterine fibroids. Clinic. In some cases, uterine fibroids go away without any symptoms, and women do not have any complaints, but they are detected when a woman is examined for prophylaxis. In $60-80 \%$ of cases, one of the main symptoms is bleeding in the patient.

Bleeding symptoms vary from patient to patient. Some have a prolonged menstrual cycle or a slight increase in blood flow during menstruation - menorrhagia, while others have irregular, excessive bleeding, which can lead to severe anemia. Menstruation lasts for 10-12 days and causes a lot of bleeding, which is called hyperpolymenorrhea. Another common symptom of fibroids is pain. The pain is similar to that of a stinging pain, especially before and during menstruation, and is exacerbated as a pull-down, which is a sign of post-inflammatory adhesions. The pain depends on the size of the tumor and where it is located. If the tumor fills the entire small pelvic cavity, the tumor disrupts the function of neighboring organs. Tumors located under the lining of the uterus cause severe pain when menstrual blood is collected during menstruation, as well as tumors under the lining of the uterus. Tumor infection is an inflammation of the small pelvic organs, and pain occurs in 2/3 of patients with uterine fibroids. The pain also occurs when the subserosal tumor is twisted, as the blood vessels in the tumor are twisted and the nutrition of the tumor is impaired.

MATERIALS AND METHODS
The cure. All women with fibroids are initially treated in general, and if conservative treatment is ineffective, the uterus is surgically removed.

Endometriosis. Endometriosis is the development of a cell in the lining of the uterus (endometrium) outside the uterus. Symptoms of endometriosis include proliferation, secretion, or menstrual bleeding-like symptoms, such as cyclic changes in the lining of the uterus caused by steroids and gonadotropin-releasing hormones. Endometriosis has the ability to grow into surrounding tissues. This can have a proteolytic effect on the tissues, breaking them down and damaging even deeper parts. Endometriosis has an uneven border that extends to the serous, muscular, and mucous membranes, skin, bone marrow, and even bone tissue. When the endometriosis bladder ruptures, it spreads to all parts of the body through the blood and lymphatic system. Among gynecological diseases, endometriosis occurs in $8-30 \%$ of cases.

Clinic. depending on the area in which the endometriosis is located. One of the most common and persistent symptoms of endometriosis is pain. The patient complains of mild, prolonged pain in the lower abdomen and lower back, with increased pain during the menstrual cycle. The pain appears before the menstrual period and intensifies during and after the menstrual period. These pains are caused by swelling of the glandular tissue in the focus of endometriosis, the accumulation of fluid in the closed cavities of the tissue. Endometriosis of the uterus leads to disruption of the menstrual cycle, dysfunction of neighboring organs - the rectum, urinary tract. Accordingly, the woman complains of pain during urination and frequent urination. An organ with endometriosis is seen to enlarge 
before menstruation and return to its original size after menstruation. In the absence of ovulation in the patient, the secretory phase is underdeveloped, scarring occurs in the small pelvic organs, often accompanied by signs of inflammation, leading to infertility.

The cure. Treatment is conservative or operative, depending on the patient's age, localization, prevalence, and signs of inflammation of the surrounding tissue.

Ovarian benign tumors.

Ovarian tumors account for $6-8 \%$ of gynecological diseases that occur at different ages in women. The disease is very dangerous because it grows slowly and does not cause any symptoms. Symptoms appear after the addition of complications, but unfortunately, treatment is not useful at this time. Ovarian tumors are most common between the ages of 20 and 40 , and in $20-25 \%$ of cases they become malignant.

\section{RESULT AND DISCUSSION}

A true tumor of the ovary is called a cystoma, and a retention or tumor is called a cyst. Retention cysts are secretions that form as a result of the accumulation of secretions produced by the glands of tumor cysts, which account for $34 \%$ of cysts. Follicular cysts (75\%), corpus luteum cysts (5\%), tuboovarial, paraovarial, intraligamentary cysts (10\%). Endometriotic cysts are also found in the ovaries. Follicular cysts are more common in fibroids, while luteal cysts are more common in gallbladder and chorionic epitheliomas. The follicles do not rupture and develop without yellowing, which means that the menstrual cycle is disrupted. These cysts are round, no more than $6-8 \mathrm{~cm}$ in diameter, and often have no clinical signs. Acute abdominal symptoms are rarely associated with cystic fibrosis.
Retention cysts are usually treated conservatively (anti-inflammatory drugs, immunocorrectors).

Blastomatous cysts are true tumors, accounting for $66 \%$ of ovarian tumors. Tissue proliferation, the filling of cavities with fluid, leads to the growth of tumors. According to the growth of various tissues - epithelial, connective tissue, teratoid and hormonal ovarian tumors. True tumors, in turn, are divided into benign and malignant tumors. Benign tumors grow outside the ovary. Normal serous cysts are one of the most common ovarian tumors. It can grow from $8 \mathrm{~cm}$ to $30-40$ $\mathrm{cm}$ and even cover the entire abdomen.

A cystoma is usually single-chambered, with a thin, flat spherical cortex and an elastic consistency. Serous fluid collects in its cavity. The tumor is usually located on one side - left or right - and is mobile in the abdomen because it has an anatomical "leg" consisting of the ovaries and fallopian tubes. As the cyst grows, these lengths lengthen, coming closer together to form the base of the tumor.

Complications. When a woman works, bends, or lies on her side, the tumor moves from left to right or from right to left, and can often twist 180-360 degrees. The patient may experience severe pain in the lower abdomen, nausea, vomiting, palpitations, and the appearance of Shyotkin-Blumberg syndrome in the lower abdomen. This condition is called "acute abdomen". In this case, the patient should be immediately admitted to the gynecology department and operated immediately.

\section{CONCLUSION}

Ovarian fibroids are considered to be tumors of the connective tissue of this organ. Ovarian fibroids are rare (7-5\%) and are often 
associated with uterine fibroids. The most typical forms of teratomas are dermoids. Dermoids are benign tumors that make up about $10 \%$ of all ovarian tumors. Their structure usually involves three embryonic layers. Dermoids are spherical smooth tumors that grow slowly, have limited mobility, and are often located in the space between the uterus and the bladder. When a dermoid cyst is cut, it looks like a bag full of fluid. This liquid solidifies at room temperature to form an oily mass. Fatty masses often contain elements from the early stages of human embryonic development - hair, teeth, nails, and the like.

\section{REFERENCES}

1. Avetisyan T.G. Reproductive function of the uterus after operative treatment of diseases of the uterus. Autoref. diss. ... Na soiskanie uchenoy stepeni kandidata meditsinskix nauk Moskva, 2008. 26 p.

2. Aylamazyan E.K. "Obstetrics: national leadership" - M .: "GEOTAR-Media", 2013.

3. Badretdinova F.F., Trubina T.B., Khasanov A.G., Magafurov R.F. Some aspects of prophylaxis and treatment posledstviy akusherskoy travmi sheyki matki Lechenie i profilaktika № 2 (14) 2015 C. 5-10.

4. Badretdinova F.F., Khasanov A.G., Trubin V.B. Some aspects of the classification of rubtsovoy deformatsii sheyki matki. Obstetrics, gynecology and reproduction 2014 № 3 C. 41-44.

5. Badretdinova F.F., Trubin V.B., Dodonov A.N. Akusherskie travmы sheyki matki pri pervyx roda-faktor riska razvitiya fonovyx i predrakovyx zabolevaniy sheyki matki. Perm Medical Journal 2013 № 1 (30) p. 4045.

6. Gilyazutdinova Z.Sh., M.K. Maxaylova. Oncogynecology - M., 2000. - 316 p.

7. Ivanova M.N., Minaev H.N Osobennosti techeniya beremennosti u jenshchin, perenesshix xirurgicheskuyu korrektsiyu posttravmaticheskogo ektropiona sheyki matki // Vestnik eksperimentalnoy i klinicheskoy xirurgii. - 2011. T. 4, № 2. - C. 378384.

8. Kijaev Yu.E. Kompleksnoe treatment of pain with rubtsovoy deformatsiey sheyki matki. Autoref. ... Diss. k.m.n. Moscow 2009 g 23 p.

9. Kulakov V.I. «Manual of outpatient polyclinic assistants in obstetrics and gynecology»- M .: «GEOTAR-Media», 2007. 